\title{
NEGATIVE IMPACTS OF PSYCHOLOGICAL PROBLEMS ON THE PROTAGONIST IN FAYE BIRD'S NOVEL MY SECOND LIFE
}

\author{
Dinda Femilya Utari, M. Manugeren \\ Faculty of Literature \\ Universitas Islam Sumatera Utara (UISU), Medan, Indonesia \\ e-mail: dndfemilya@gmail.com
}

Received: 2021-04-21

Accepted: 2021-05-22

\begin{abstract}
The objective of this study is to find out the psychological problems on the protagonist and the negative impacts caused by the psychological problems in Faye Bird's novel My Second Life published in 2014. Psychological problem are disorders of cognitive, volition, affective, and psychomotor generating to psychological disorders characterized by abnormal thoughts, feelings, and behaviors. The two aspects of the problems are in reality get into the corridor of psychology, a study about human's soul or mind, either about its symptoms, processes, or its background. As literature is a reflection of society, all the characters are also members of literary community leading to a concept that psychology and literature are closely related. This novel is about a teenager who experiences various psychological problems after finding out that in her first life she has been the cause of someone's death. This study is conducted to give an overview to all people about the negative impacts of psychological problems experienced by the protagonist. This study applies qualitative method going through social phenomena and the data are collected from the novel. The results show the psychological problems are depression, anxiety and trauma causing negative impacts in the forms of insomnia, lack of concentration and truancy.
\end{abstract}

Keywords: depression, anxiety, trauma, insomnia, lack of concentration, truancy

\section{Introduction}

My second Life, is a 258 pages novel, written by Faye Bird, originally published in 2014, and republished in January 2016. This novel is Faye Bird's debut novel. Bird previously worked as a literary agent then moved to be a screen writer for films and TV. Bird writes fiction for young adults, and besides My Second Life, she has published two other books, What I Couldn't Tell You (2016) and My Secret Lies with You (2019).

My Second Life is the story of a teen living her second life then haunted by the killing of someone in her first life. Fifteen-year-old Ana was born in the year 2000 to Rachel who loves her deeply. But Rachel "doesn't feel like Mum" to Ana, because Ana is not really Ana: she had been born before in 1972, and died at age of 22. She still feels like a girl named Emma, and she misses her real mother. An accidental meeting with an 
Negative Impacts of Psychological Problems on The Protagonist in Faye Bird's Novel My Second Life, Dinda Femilya Utari, M. Manugeren

old woman named Frances makes Ana remember the events in her previous life one by one. When she becomes Emma, she kills a little girl, Frances's daughter. Ana starts visiting Frances on the same street where Emma grows up to find out the truth about the death of her daughter. Never finding clarity about the death of Frances's daughter, Ana could not sleep because of fear and feeling traumatized. Tormented by lingering memories and powerful feelings from early childhood, Ana begins to put the pieces together, but full understanding is impossible until Frances and Ana sits down with Emma's parents.

This study is concerned with two points of discussion, namely the protagonist's psychological problems: depression, anxiety and trauma and the negative impacts of psychological problems: insomnia, lack of concentration and truancy. The first psychological problem is depression, an emotional condition that is usually characterized by very deep sadness, feelings of meaninglessness and feelings of defeat withdrawing, unable to sleep, loss of appetite and interest in daily activities. Depression is the condition when people are sad, broken hearted, or losing someone or something in their life. Depression gives bad mental influences for those who feel it (Goodman, 2011: 32); secondly, anxiety, a subjective feeling about disturbing mental tension as a general reaction of the inability to cope with a problem or the absence of a sense of security. These uncertain feelings are generally unpleasant which will lead to or be accompanied by physiological and psychological changes (Rochman, 2010: 104). Basically, anxiety is a natural thing that has been experienced by every human being, and has been considered as part of someone's daily life. However, excessive anxiety will prevent a person from living his life; and thirdly, trauma and according to Heidarizadeh (2015), trauma means a traumatic event which involves a single event or experience; it involves the feelings and emotions.

The impacts are as follows: The first is insomnia. Insomnia is a disorder of difficulty in sleeping at night. Insomnia is a state of inability to get good sleep, both in quality and quantity, with a state of short sleep or insomnia (Alimul, 2006). The second is lack of concentration. Lack of concentration will greatly hinder a person from carrying out their activities. It will make it difficult for them to focus and think. The third is truancy. Truancy is a deliberate absence by students without the knowledge of the teacher and parents. Truancy is a bad behavior.

\section{Literature Review}

\subsection{Psychological Problem}

A psychological problem also refers to psychological disorder. A psychological disorder is a condition characterized by abnormal thoughts, feelings, and behaviors (Weiser, 2014). Psychological problems are disorders of cognitive, volition, affective, and psychomotor. Psychological problems are symptoms or psychological patterns of behavior that appear clinically that occur in a person because they are associated with a state of distress (pain symptoms) or disability (disorders in an area or more important functions) which increases the risk of death, pain, disability or loss of essential liberty and it is not uncommon for responses to be received under certain conditions. This disorder can happen to anyone. This psychological disorder occurs due to various factors such as, traumatic events such as violence and sexual harassment, loss of the closest people, feelings of inferiority, inadequacy, anger and loneliness. 


\subsubsection{Depression}

Depression is a feeling of sadness associated with suffering. It can be a selfdirected attack or a deep feeling of anger (Nugroho, 2000). Depression is a common mental disorder that presents with depressed mood, loss of interest or pleasure, decreased energy, feelings of guilt or low self-worth, disturbed sleep or appetite, and poor concentration. These problems can become chronic or recurrent and lead to substantial impairments in an individual's ability to take care of his or her everyday responsibilities (Bhowmilk, 2012). According to Lyer and Khan (2012) major depression is a mood disorder characterized by a sense of inadequacy, despondency, decreased activity, pessimism, anhedonia and sadness where these symptoms severely disrupt and adversely affect the person's life, sometimes to such an extent that suicide is attempted.

Depression is a mood disorder that is common in society. However, depression is a disease that is not widely detected. Mild depression affects a person's daily activities, while severe depression can lead to suicide attempts. According to American Psychiatric Association (2013), several symptoms are common to someone who is experiencing depression, such as:

1. Depressed mood most of the day, nearly every day.

2. Markedly diminished interest or pleasure in all, or almost all, activities of the day, nearly every day.

3. Significant weight loss when not dieting or weight gain.

4. Insomnia or hypersomnia nearly every day.

5. Psychomotor agitation or retardation nearly every day.

6. Fatigue or loss energy nearly every day.

7. Feelings of worthlessness or excessive or inappropriate guilt (which may be delusional) nearly every day.

8. Diminished ability to think or concentrate, or indecisiveness, nearly every day.

9. Recurrent thoughts of death (not just fear of dying), recurrent suicidal ideation without specific plan, or a suicide attempt or a specific plan for committing suicide.

\subsubsection{Anxiety}

Anxiety is total response of a human being to threat or danger. Each experience of anxiety involves a perception of danger, thoughts about harm, and a prose of psychological alarm and activation (Moss, 2002). While according to Hallam (1992), anxiety is a word used in every day conversation and refers to a complex relationship between a person and his situation. Anxiety is often a diffuse, unpleasant and uncomfortable feeling of apprehension, accompanied by one or more bodily sensations that characteristically recur in the same manner in the person. Anxiety disorders can make it hard for people to work or study, to manage daily tasks and to relate well with others (Rector, 2005).

Anxiety is a normal feeling people experience when faced with threat, danger, or when stressed. When people become anxious, they typically feel upset, uncomfortable, and tense. Feelings of anxiety can be a result of life experiences, such as relationship breakdown, serious illness, major accident, or the death of someone.

\subsubsection{Trauma}

Trauma is a word derived from Greek, which means "wound", and originally implied an injury inflicted upon the body, but today implies a wound inflicted upon the 
Negative Impacts of Psychological Problems on The Protagonist in Faye Bird's Novel My Second Life, Dinda Femilya Utari, M. Manugeren

mind. In other words, trauma is the event and the emotional and physical response long after the event occurred. While according to Smith (2008), trauma is the result of extraordinarily stressful events that shatter your sense of security, making you feel helpless and venerable in a dangerous world. Traumatic experiences often involve a threat to life or safety. Experience is involving betrayal, verbal abuse, or any major loss. An event can be called a traumatic event that causes extreme stress and exceeds the individual's ability to cope (Giller, 1999). The traumatic event can be re-experienced in various ways. A common re-experiencing symptom is distressing dreams that replay the event itself or that are representative or thematically related to the major threats involved in the traumatic event. These episodes, often referred to as "flashbacks," are typically brief but can be associated with prolonged distress and heightened arousal.

\subsection{Negative Impacts of Psychological Problem}

Psychological disorders will get worse over time if not treated immediately. People with psychological disorders will experience several signs and symptoms both emotionally and physically. Emotionally, the person who is traumatized will experience emotional symptoms that often appear, such as denial or cannot accept reality, angry, sad, overflowing emotions, feeling embarrassed, feeling guilty of what happened, and withdrawing from association. Whereas psychically, the symptoms are such as paleness, limpness, fatigue, lack of concentration, and heart beating fast.

\subsubsection{Insomnia}

Someone who has a psychological disorder generally will feel difficulty in sleeping at night. This happens because of mood disorders that cause sufferers to feel sad, hopeless, helpless and guilty. All these negative emotions occupy their minds, making it difficult for them to sleep. Insomnia is a condition that describes a person having difficulty sleeping. These conditions can include trouble sleeping, waking up frequently at night, and waking up too early. This condition results in a feeling of not being refreshed during the day and difficulties in carrying out daily activities and not fulfilling the need for good sleep (Respir, 2014).

\subsubsection{Lack of Concentration}

Psychological disorders can make sufferers less concentrated or less focused on what is being done. This is because the sufferer is constantly overshadowed by a memory that the sufferer does not want to remember, so that the sufferer often daydreams and eventually loses concentration.

They will generally experience difficulty to think, concentrate, or make even minor decisions. They may appear easily distracted or complain of memory difficulties. In the case of school-aged children, this psychological disorder will greatly affect the decline in school grades because the child will have difficulty concentrating while studying, or may even fall asleep in class while teaching and learning activities are in progress.

\subsubsection{Truancy}

Truancy is one of the negative effects caused by psychological disorders. According to Mustaqim and Wahib in Khanisa (2012: 28) truancy is a form of action that students deliberately leave lessons or leave school without prior permission or without information; not attending school for the wrong reasons and for no apparent 
reason. School-age children with psychological disorders tend to skip school, because they experience extreme mood swings that make them lose interest or pleasure in things he used to do. Individuals may be feeling less interested in hobbies, not caring anymore, or not feeling any enjoyment in activities that were previously considered pleasurable.

\section{Research Method}

The research method used is qualitative research design. The data are taken from many texts and are then explored and analyzed using descriptive qualitative method by identifying clauses, sentences and interpreted into the form of words rather than numbers (Creswell, 2013: 87). The application of this qualitative method is descriptive in nature, which means the data generated in the form of words in the form of quotations.

According to Bogdan in Moleong (2007: 4), the qualitative method is a research procedure that produces descriptive data in the form of written or oral words from people and observed behavior. Thus, this approach is directed at the setting and the individual holistically (whole). The main data in this study are taken from Faye Bird's novel My Second Life, and the source of data are from the phrases and sentences of the novel. Then

\section{Discussion}

This part will be divided into two points of discussion: the protagonist's psychological problems, sub-divided into depression, anxiety and trauma and the negative impacts of psychological problems, sub-divided into insomnia, lack of concentration, and truancy. Each negative impact of psychological problem is described below.

\subsection{The Psychological Problem \\ 4.1.1 Depression}

Guilt is one of the symptoms of depression experienced when someone is depressed. Feelings of guilt arise because a person feels that others will suffer as a result of a mistake he has made. As in this novel, the protagonist feels that if she has not left her childhood friend, Catherine, alone by the lake, she probably would not drown in the lake.

Guilt. All I could feel was guilt. It was uncoiling itself inside me. (Bird, 2016: 20). ... I might not have remembered leaving her to cough and splutter as her lungs filled up, until there was not a breath of her left, but I knew right down to my core that I'd killed her, that I was guilty. And I couldn't get the image of her face in the water out of my mind (Bird, 2016: 29).

Based on the quotations above, the protagonist continues to feel guilty for what has happened in the past. She feels that she is the cause of her childhood friend's death, so the images of what happen when her friend dies and floats on the surface of the lake keeps filling her head. Not for a second the image disappears from her mind. This shadow haunts the life of the protagonist and makes feelings of guilt continue to envelop her.

Not only feelings of guilt, the protagonist also has other symptoms of depression, namely fatigue and lack of energy. The body that is easily tired is 
Negative Impacts of Psychological Problems on The Protagonist in Faye Bird's Novel My Second Life, Dinda Femilya Utari, M. Manugeren

associated with depressive symptoms because depression takes a lot of one's energy in thinking about something, so that people with depression will feel easily tired in carrying out their daily activities.

I held on to the mantelpiece and my eyes began to go again. I was weak. (Bird, 2016: 196) ...I fell to the floor. I felt my legs go, and I opened my mouth to cry out, but I knew I was going to hit the floor and there was nothing I could do about it (Bird, 2016: 199).

From the quotation above, the protagonist feels her body is getting tired because she keeps trying to collect memories about the incident on the day her childhood friend dies. Because of that she has to think hard which eventually draining her strength as she tries to remember the things that has happened in her first life, and also to find out the truth about Catherine's death.

\subsubsection{Anxiety}

Feelings of anxiety tend to be characterized by a feeling of fear that is unclear or unpleasant. One of the most common symptoms of anxiety is panic attacks. Someone who has anxiety tends to be prone to panic attacks when they have to be exposed to situations that can trigger their anxiety. In this novel, the protagonist tends to be more prone to panic attacks when she is faced with a situation related to the past that she really does not want to remember.

I felt panicked now. A vague sickness began to shift and rise in my belly (Bird, 2016: 92) ...

And I felt a panic rising up inside me, fast and urgent, and I thought I'd be sick with the guilt and the shame (Bird, 2016: 180) ... Panic gripped me, as it had then. Frances. She'd seen me. I'd been seen. I felt sick with them knowing what I did (Bird, 2016: 188).

The above quotes show that the protagonist experiences panic attacks several times when she is faced with situations related to Catherine's death and also when she receives new memories about the events of the day Catherine dies.

\subsubsection{Trauma}

Trauma occurs because someone witnesses a painful incident that makes someone unable to forget, and is also constantly shadowed by the incident. In this novel, the protagonist experiences the trauma of seeing the death of her childhood friend drowned in a lake, in her previous life, when she is Emma. Symptoms of trauma that occur in the protagonist are often experienced by flashbacks related to the death of her friend and she also has nightmares.

We're going to the river, Cathrine. We'll play hide-and-seek by the river. Those words just wouldn't go away. If you don't play I'll tell on you. You have to come or that's what I'll do (Bird, 2016: 64).

The quotation above shows that the protagonist begins to remember the actual events one by one. This is what makes the protagonist under pressure because she cannot remember the actual events at once, but one by one, which of course will make her feel even more burdened by curiosity about what really happens, and whether it is true that she is the reason for Catherine's death. 


\subsection{Negative Impact of Psychological Problem}

\subsubsection{Insomnia}

As long as Ana has a psychological breakdown, she experiences insomnia. Ana also feels that sleeplessness is part of her life. She is too focused on the problem at hand, so that the events that disturb her mind often haunt her, making it difficult for her to sleep.

I didn't sleep. I couldn't. Being shouted like that, being hit. It stayed with me. I lay in bed, still, all night, with my eyes open, trying to feel blank. Trying to feel nothing. But my feelings were all over me, like itches I couldn't reach to scratch (Bird, 2016: 104).

The quotations above show that the protagonist is having trouble in sleeping. Even though she has tried to lie on her bed all night with her eyes closed, she still cannot fall asleep. The images of the memories continue to roll even as she closes her eyes. Her mind keeps turning past events that makes her having trouble in sleeping.

\subsubsection{Lack of Concentration}

Lack of concentration is one of the negative impacts arising from psychological disorders. Those who suffer from psychological disorders tend to find it difficult to focus on what they are doing. Their minds are constantly filled with events that weigh down on them.

I shook my head. My eyes wouldn't focus and my mind just wasn't giving me any kind of a break; it was full of images almost all the time. They were churning, spinning, repeating over and over. I thought I might pass out, but I didn't. I couldn't. However tired I was, I seemed to always be conscious (Bird, 2016: 165).

From the quotation above, it can be seen that the protagonist has difficulty in concentration because her mind is filled with images of events about Catherine. The incident continues to spin her head endlessly. Even when she is tired, these events does not disappear from her mind.

\subsubsection{Truancy}

Truancy is a negative impact felt by the protagonist. A child in school age who suffers from psychological problems is prone to truancy. She will feel safer and also more comfortable outside of school.

I didn't go to the toilets. I walked straight out of school and into the street, and I just kept walking. I wasn't really sure where I was going. I felt less sick now that I was outside. I guessed the school would call Rachel once they'd realized that I had gone. I'd never ditched before. I didn't really know how these things worked. I had been in for registration. Maybe no one would notice that I had gone. I looked at my watch. It was just after midday... (Bird, 2016: 29).

From the quotation above, the protagonist deliberately leaves her class when the flashback pieces fill his head. She leaves her class on the excuse of going to the toilet, but she does not actually go to the toilet. She leaves school and then goes to the train 
Negative Impacts of Psychological Problems on The Protagonist in Faye Bird's Novel My Second Life, Dinda Femilya Utari, M. Manugeren

station, and gets on it. She leaves with no apparent purpose. She just does not want to be in school.

\section{Conclusion}

Based on the analysis of the problem in the novel, some significant points of research are found. The psychological disorders are experienced by the protagonist making her feel various symptoms which eventually result in her experiencing some effects of these symptoms in her daily life.

The protagonist experiences various psychological problems since knowing that she has lived before and when she sees that her childhood friend from her first life has died. The protagonist experiences three psychological problems. The first is depression, which is characterized by symptoms of guilty, loss of energy and thought of suicide. The second is anxiety, characterized by symptoms of insomnia. And the third is trauma, characterized by flashback symptoms and nightmares.

The psychological problems suffered by the protagonist have negative impacts on the protagonist. The first impact is insomnia. The protagonist experiences insomnia as a result of the psychological problems. Events that disturb her mind keep filling her head even as she is about to go to sleep. The second is lack of concentration. Flashbacks that keep spinning in her head make her easy to lose concentration on what she is doing. And, the last is truancy. All these negative impacts appear since the protagonist has psychological problems.

\section{References}

Alimul, Aziz. (2006). Pengantar Kebutuhan Dasar Manusia: Aplikasi Konsep dan Proses Keperawatan. Jakarta: Salemba Medika.

Bhowmik, D., Kumar, S., et al. (2012). Depression - Symptoms, Causes, Medications, and Therapies. The Pharma Innovation.

Bird, Faye. (2016). My Second Life. New York: Farrar, Straus and Giroux

Creswell, WJ. (2013). Mixed Method Research. Nebraska: University Press.

Giller, E. (1999). What is Psychological Trauma? www.sidran.com.

Goodman, C Catherine. (2011). Depression: Clinical Guide. Rome: Kent Publishing Company.

Hallam, R. (1992). Counselling for Anxiety Problems. London: Sage Publications.

Heidarizadeh, Negin. 2015. The Significant Role of Trauma in Literature and Psychoanalysis. Iran. https://www.researchgate.net/publication/282555646.

Iyer, Khan. Z.A. (2012). Depression-A Review. Research Gate. https://www.researchgate.net/publication/273769453_Depression_-_A_Review

Khanisa, S. (2012). Pengaruh Layanan Konseling Kelompok dengan Menggunakan Teknik Pendekatan Behavior untuk Mengatasi Perilaku Membolos. Semarang.

Moleong, J. Lexy. (2007). Metodologi Penelitian Kualitatif. Bandung: PT. Remaja Rosda Karya.

Moss, Donald. (2002). Psychological Perspectives: Anxiety Disorders. Research Gate. https://www.researchgate.net/publication/259560188_psychological_perspective s_anxiety_disorders_identification_and_intervention/.

Nugroho, W. (2000). Perawatan Lanjut Usia Perawatan Genotik. Jakarta: Penerbit Buku Kedokteraan EGC.

Rector, Bourdeau, et.al. (2005). Anxiety Disorders. https://camh.ca/-/media/files/guideand-publications/anxiety-guide-en.pdf. 
Respir, A. J. (2014). Insomnia. American Thoracic Society, 190, P9-P1. http://www.sleepeducation.

Rochman, K. L. (2010). Kesehatan Mental. Purwokerto: Fajar Media Press.

Smith, M, Segal Regal, J. (2008). Post-traumaticStress Disorder (PTSD): Symptoms, Treatment, and Self-help. http://www.helpguide.org/mental/post_traumatic_stress_disorder_symptom_trea tment.htm.

Weiser, Eric B. (2014). Psychological Disorder. Research Gate. https://www.researchgate.net/publication/291348876_psychological_disorders/. 